\title{
TWO NEW FISH SPECIES OF THE GENUS SCHISTURA MCCLELLAND (CYPRINIFORMES: BALITORIDAE) FROM WESTERN GHATS, INDIA
}

\author{
Sreekantha ${ }^{1}$, K.V. Gururaja ${ }^{2}$, K. Remadevi ${ }^{3}$, T.J. Indra ${ }^{4}$ and T.V. Ramachandra ${ }^{5, *}$ \\ 1,2,5 Energy and Wetlands Research Group, Centre for Ecological Sciences, Indian Institute of Science, Bangalore, Karnataka 560012, India \\ ${ }^{3,4}$ Zoological Survey of India, 130, Santhome High Road, Chennai, Tamil Nadu 600028, India \\ E Mail: ${ }^{1}$ sreekantha@ces.iisc.ernet.in; ${ }^{3}$ remadevi_zsi@yahoo.com; ${ }^{5, *}$ cestvr@ces.iisc.ernet.in (* Coressponding author)
}

web supplement

\begin{abstract}
Schistura nagodiensis and $\mathrm{S}$. sharavathiensis are the new fish species described from Sharavathi river, central Western Ghats. These species are distinct from their closest congeners in Schistura, which are evident from variations in the combination of characters such as processus dentiformis, barbels, bars on body, extent of lateral line with pores, marks on lower lip, ray counts, shape of caudal fin, caudal bar, adipose crest, etc. Distinct clusters of Principal Components based on morphometric variables (PCA) further substantiate that these are significantly different from their closest congeners.
\end{abstract}

\section{KEYWORDS}

Nemacheiline fishes, new descriptions, Principal Component Analysis (PCA), Schistura nagodiensis, S. sharavathiensis Sharavathi river, Western Ghats

\section{AbBreVIATIONS}

CES - Centre for Ecological Sciences; IISc - Indian Institute of Science; ZSI - Zoological Survey of India; SRS - Southern Regional Station; WGBIS - Western Ghats Biodiversity Information System; SL - Standard length.

The freshwater fish family, Balitoridae has been divided into two sub-families; Balitorinae and Nemacheilinae. Balitorinae consists of genera Bhavania, Homaloptera, Travancoria and Balitora, whereas Aborichthys, Triplophysa, Acanthocobitis, Yunnanilis, Neonemacheilus, Nemacheilichthys, Oreonectes, Longischistura, Physoschistura, Schistura, Mesonemacheilus and Nemacheilus belong to the Nemacheilinae. Of these, Schistura McClelland, 1838 has the largest assemblage of Nemacheiline species (Jayaram, 1999), which inhabits mainly hill streams, waterfalls and also penetrates into sub-terranean region (Vidthayanon, 2003), having wide distribution throughout South, Southwest and Southeast Asia. Western Ghats of India with a distinct biogeographical regime, has six taxa, namely $S$. semiarmatus, $S$. denisoni denisoni, $S$. nilgiriensis, S. kodaguensis, S. denisoni mukambbikaensis and S. denisoni pambaensis (Jayaram, 1999). Recent discoveries of fish species in Western Ghats conforms Dahanukar et al. (2005) highlight that there are many more unexplored species in the region, which requires detailed field investigations.

Ichthyodiversity and species distribution studies carried out in Sharavathi river basin, Western Ghats (Fig. 1) covering all seasons and microhabitats over a period of 36 months has led to the discovery of two new species of Schistura in ecologically sensitive habitats as well as provided insight into habitat preference of many endemic and rare species.

\section{Materials And Methods}

Specimens were collected using a $1 \mathrm{~m} \times 2 \mathrm{~m}$ net, dragging at the bottom of the streams and preserved in $6 \%$ formaldehyde, and were deposited at the Southern Regional Station, ZSI and CES, IISc. These specimens were classified as per Jayaram (1999) and compared using Menon (1987); Kottelat (1990); Talwar and Jhingran (1991); Kottelat (2004); Vishwanath and Shanta (2004); Vishwanath and Nebeshwar (2004); Vishwanath and Sharma (2005). Menon (1987); Kottelat (1990); and Jayaram (2002) were referred for terminologies and Kottelat (1990) for counts and measurements. Morphological measurements were done with a slide caliper $(0.1 \mathrm{~mm}$ precision). Thirty-one (26 nophometric and 5 meristic) characters of new species and congeners were analysed using Principal Component Analysis (STATISTICA, 1999).

\section{Schistura nagodiensis sp. nov.}

\section{Material examined}

Holotype: 26.xii.2003, Sharavathi river (13054'40"N-74053'49"E), Algod, Shimoga, Karnataka, coll. Sreekantha and Vishnu D, F-7595 ZSI/SRS, 28.0mm SL.

Paratypes: 12 exs., Sharavathi river (13054'40"N-74053'49"E), Algod, Shimoga, Karnataka, coll. Sreekantha and Vishnu D, 28.0mm SL and 25.0mm SL, F-7596 ZSI/SRS, 26.xii.2003; 25.0mm $\mathrm{SL}, 25.0 \mathrm{~mm}$ SL, 26.0mm SL, 25.0mm SL, 26.0mm SL, 26.0mm SL, $25.0 \mathrm{~mm} \mathrm{SL}, 26.0 \mathrm{~mm}$ SL, $25.0 \mathrm{~mm}$ SL and $23.0 \mathrm{~mm} \mathrm{SL} \mathrm{IISc/CES/}$ WGBIS: 3-5-3-5-007.

\section{Etymology}

Named after its type locality, Nagodi tributary of Sharavathi river, central Western Ghats.

\section{Diagnosis}

A species of Schistura depicted in Image $1^{\text {w }}$, distinguishable from other members by the following combination of characters; processus dentiformis present; 6-9 broad dark brown bars on body, the anterior bars not reaching ventral side; males without a suborbital flap; posterior extremity of anterior nostril prolonged in a filament; incomplete lateral line extending to half length of pectoral with 8-10 pores; lower lip with a black mark on each side of median interruption (Image $2^{\mathrm{w}}$ ); $81 \frac{1}{2}$ dorsal rays, 7-9 pectoral, 6 pelvic and $9+9$ caudal rays; deeply emarginate or slightly forked caudal fin; black basal caudal bar, sometimes interrupted; caudal fin with two rows of spots; no axillary pelvic lobe; anus much nearer to anal fin; weakly

${ }^{w}$ See Images in the websupplement at www.zoosprint.org

(c) Zoo Outreach Organisation; www.zoosprint.org Manuscript 1386; Received 29 June 2005; Revised received 04 January 2006; Finally accepted 07 March 2006; Date of publication 21 March 2006 April 2006 | ISSN 0973-2535 (Print edition); 0973-2551 (Online edition) 


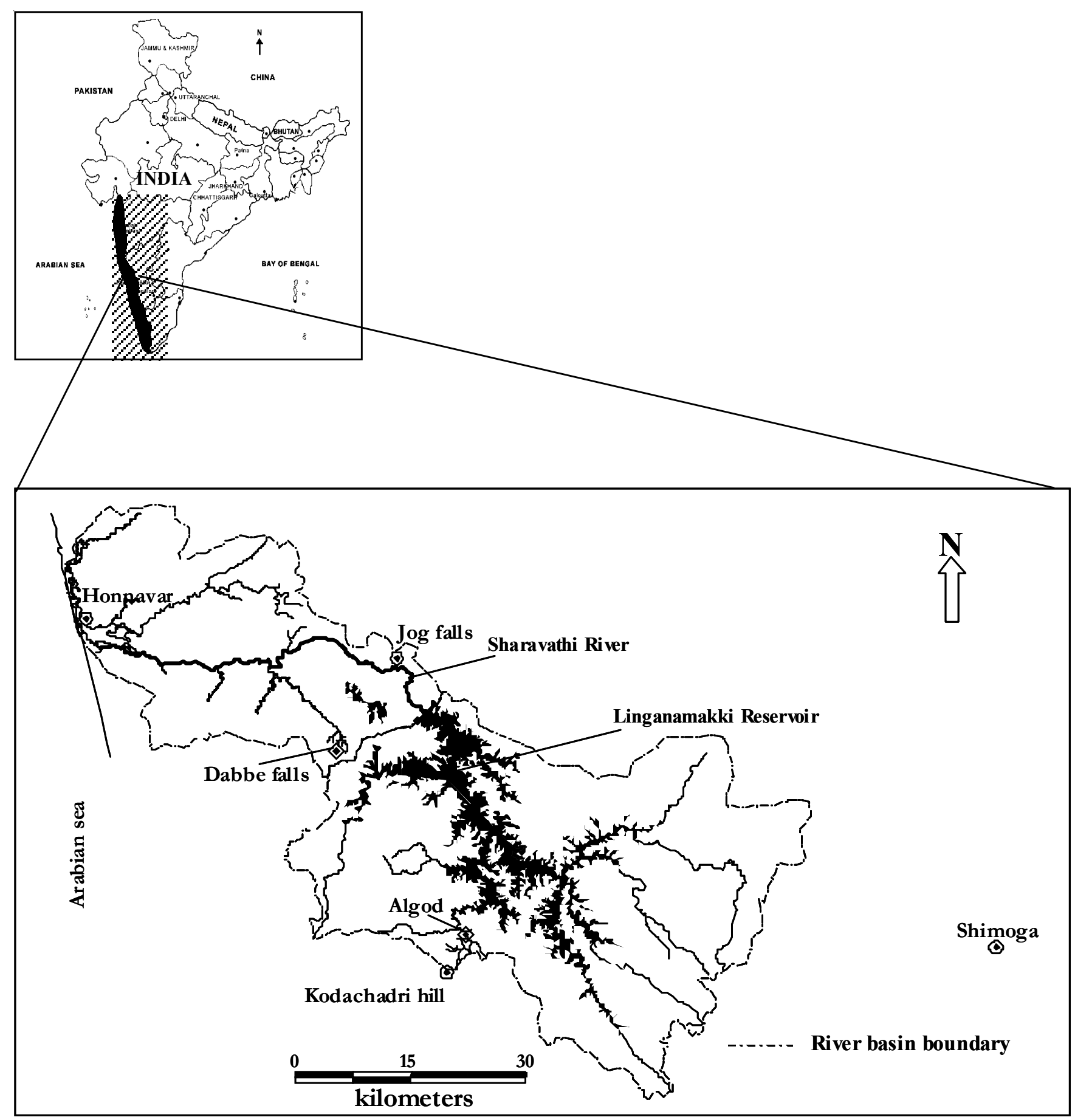

Figure 1. Sharavathi river basin with type localities of Schistura nagodiensis $(\diamond)$ and Schistura sharavathiensis $(\diamond)$.

developed adipose crest on peduncle.

\section{Description}

Morphological data and their proportionate values are listed in Tables 1 and 2 respectively. A relatively small species (largest $28 \mathrm{~mm}$ in SL) compared to other species of Schistura with moderately elongated body, rounded anteriorly to origin of dorsal fin, slightly compressed thereafter; head depressed; snout obtuse; mouth semi-circular; lips thin, upper lip with a small incision in the middle, lower lip with a black mark on either side of median interruption; anterior nostril pierced in the front, posterior extremity prolonged in a filament; eyes large, diameter equals inter orbital width; barbels-inner maxillary shorter than outer, outer maxillary shorter than nasal, not extending to margin of eye; processus dentiformis present; incomplete lateral line with 8-10 pores, extending to half length of pectoral fin; cephalic lateral line system with 6 supraorbital, 4+10 infraorbital, 9 preoperculomandibular and 3 supratemporal pores; fin ray 
counts, dorsal $2 / 8^{1 / 2}$, pectoral $7-9$, pelvic $1 / 6$, anal $2 / 5$ and caudal $9+9$; dorsal fin equidistant from tip of snout to caudal fin base; distal margin of dorsal fin slightly convex; pelvic fin inserted slightly behind the origin of dorsal fin; anal fin at three quarters of SL, not reaching base of caudal fin; pectoral fin reaches half the distance to pelvic origin, pelvic fin extends beyond anus; caudal fin without axillary lobes, varies from deeply emarginate to slightly forked; weakly developed adipose crest on caudal peduncle.

\section{Colour}

Live specimens (in natural condition) light yellowish-brown with 6-9 dark brown cross bars, broader than interspaces; preserved specimens creamy white with black cross bars; bars broader along the lateral line, without reaching ventral surface and restricted to upper two-third of body except near caudal peduncle; near caudal peduncle extend to ventral surface; head and snout mottled with dark black spots; a shade of wine red on entire body surface, intense on dorsal fin in live specimens; two rows of spots at one quarter and three quarters of the height of dorsal fin; band on caudal fin base varies from dot to dissociate to complete; a prominent dark black spot on each side of median interruption.

\section{Habitat}

Specimen was collected from the Nagodi tributary, a perennial tributary of river Sharavathi with annual rainfall of over $5500 \mathrm{~mm}$. The catchment of this tributary is endowed with numerous torrential hill streams and vegetation cover (nearly 88\%) (Figure 5 a). Vegetation cover comprises of evergreen to semi-evergreen (36.54\%), moist deciduous forests $(20.04 \%)$, plantations $(26.28 \%)$ and agricultural area $(1.03 \%)$. The species is aptly named after the tributary to signify its occurrence as well as habitat preference.

\section{Distribution}

Sharavathi river basin, Central Western Ghats, Karnataka, India

\section{Discussion}

Characters such as elongated body with almost uniform depth, blunt snout, inferior mouth, dorsal fin inserted opposite to pelvic fin, with eight branched rays, emarginate caudal fin, pelvic fins not extending up to anal fin, body with scales, a dark band on the base of caudal fin, presence of characteristic colour pattern on the body in terms of cross bands and a band at the base of caudal fin indicates that this species is a member of Schistura genus.

Diagnostic features highlight that the new taxon has unique combination of characters compared to any other species of Schistura reported so far in Menon (1987), Kottelat (1990), Talwar and Jhingran (1991), Kottelat (2004), Vishwanath and Shanta (2004), Vishwanath and Nebeshwar (2004), and Vishwanath and Sharma (2005). Comparison with the species of Western Ghats is provided in Table 3. Schistura nagodiensis is comparable only to $S$. kodaguensis Menon. However, it differs from S. kodaguensis, which has 11-14 bands, tapering below, caudal fin slightly emarginate, dorsal with a light margin

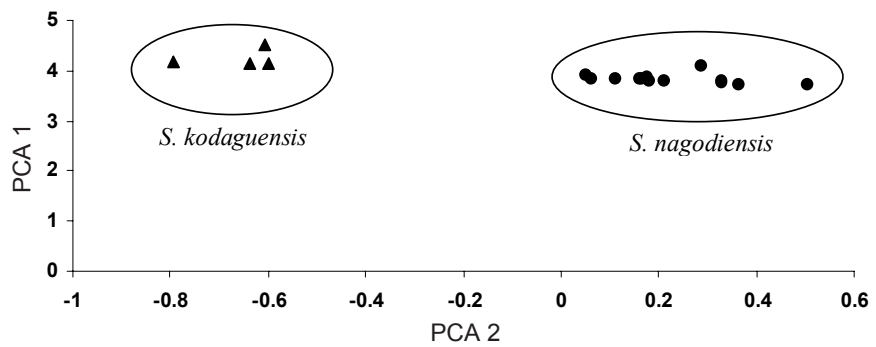

Figure 2. Plot of principal components of 31 morphological parameters - Schistura nagodiensis and S. kodaguensis

bounded below by an arched black band and a dark base. It resembles to $S$. robertsi in the presence of black mark on the median part of lower lip, prolonged nasal filament, and banding pattern on the body, while differing in caudal fin (emarginate and with one row of dark pigments on the proximal area in $S$. robertsi), dorsal branched rays $(71 / 2)$, caudal rays $(8-9+8$ in $S$. robertsi). Plot of principal components (of PCA) gives distinct clusters indicating variations between $S$. nagodiensis and $S$. kodaguensis (Fig. 2). Eigen value of PC 1 is 264.2 (accounts for $98.85 \%$ variability) and PC 2 is 2.63 . Appendix-I provides identification keys to new species.

\section{Comparative Material}

Schistura kodaguensis: 06.x.2004, Kootu Holé (12026'59"N$\left.75^{\circ} 42^{\prime} 46^{\prime \prime E}\right)$, about $8 \mathrm{~km}$ northwest of Mercara, Coorg, Karnataka, 2 exs. 23.0mm SL and 29.0mm SL, coll. Sreekantha, Vishnu D. and Gururaja K.V., IISc/CES/WGBIS: 3-5-3-5-005.

Schistura nilgiriensis: 06.xi.2003, Sharavathi river, Niluvase (13044'18"N-75006'30"E), Shimoga, Karnataka, 2 exs. 39.0mm SL. and 43.0mm SL, coll. Sameer Ali, Gururaja KV and Vishnu D, IISc/CES/WGBIS: 3-5-3-5-004.

Schistura denisoni denisoni: 21.xi.2003, Sharavathi river

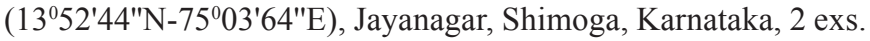
$31.0 \mathrm{~mm}$ SL and $39.0 \mathrm{~mm}$ SL, coll. Sreekantha and Vishnu D, IISc/ CES/WGBIS: 3-5-3-5-001.

Schistura semiarmatus: 23 xi.2003, Sharavathi river $\left(75^{\circ} 03^{\prime} 52^{\prime \prime} \mathrm{N}-\right.$ $13^{0} 52^{\prime} 45^{\prime \prime E) ~ S u t t h a, ~ S h i m o g a, ~ K a r n a t a k a, ~} 2$ exs. 32.0mm SL and 34.0mm SL. Coll. Sreekantha and Vishnu D, IISc/CES/WGBIS: 3-5-3-5-006.

\section{Schistura sharavathiensis sp. nov.}

\section{Material examined}

Holotype: 26.iii.2004, Sharavathi river (1408'15"N-74044'30"E), Kalkatte tributary, $1 \mathrm{~km}$ upper to Dabbe falls, Shimoga, Karnataka, 29.0mm SL, coll. Sreekantha and Vishnu D. F-7597 ZSI/SRS.

Paratypes: 26.iii.2004, 3 exs., 26.0mm SL and 24.0mm SL, ZSI/ SRS F-7598, 28.vii.2004; 26.0mm SL, IISc/CES/WGBIS: 3-5-3-5008 , locality and collectors as in Holotype.

\section{Etymology}

Named after its type locality, Sharavathi river, Central Western 
Ghats.

\section{Diagnosis}

A species of Schistura depicted in Image $3^{\mathrm{w}}$, distinguishable from other members by the following combination of characters: processus dentiformis well developed; 16-18 almost regular brown bars on body, narrower than interspaces; males without suborbital flap; nasal tube with a prolonged barbel, long with unculi; lateral line with 5-6 pores, reaching one third of pectoral fin; lower lip with a median interruption, each side with 4-5 deep furrows; $81 \frac{1}{2}$ dorsal, 9 pectoral, 7 pelvic and $7-8+8$ caudal rays, slightly emarginate caudal fin; black basal caudal bar with a darker central spot; caudal fin plain; no axillary pelvic lobe; pelvic origin below dorsal or slightly behind; anus much nearer to anal fin; a long and high adipose crest from just behind dorsal fin, a shorter ventral crest.

\section{Description}

Morphological and proportionate values of Schistura sharavathiensis are listed in Tables 1 and 2 respectively. Body moderately elongate, depth increasing to dorsal fin and thereafter tapering posteriorly; mouth semi-circular; both lips fleshy, median incision in upper lip and lower lip interrupted in the middle with 4-5 deep furrows on each side (Image $4^{\mathrm{w}}$ ); processus dentiformis well-developed; nasal tube with a prolonged barbel; head length slightly greater than depth; barbels well-developed, long with unculi; nasal barbel prolonged as in members of the genus Oreonectes of the same family; lateral line incomplete, ending at mid level of mid region of pectoral fin, with 5-6 pores, cephalic lateral line system with 6 supraorbital, 4+8 infraorbital, 9 preoperculomandibular and 3 supratemporal pores; fin ray counts include, dorsal $8 \frac{1}{2}$, pectoral 9 , pelvic $1 / 7$, anal $2 / 5$ and caudal $7-8+8$; dorsal fin equidistant from tip of snout to caudal fin base; dorsal fin with convex distal margin; pelvic fin does not reach vent and separated by a wide distance; no axillary pelvic lobe; anal fin not reaching caudal fin base; pectoral fin reaches half the distance to pelvic origin; pelvic fin reaches half the distance to anal fin without reaching anus; caudal fin slightly emarginate with rounded lobes and upper lobe longer than lower; long ventral and dorsal adipose crest present.

\section{Colour}

Body light yellowish-brown with 16-18 almost regular thin cross bars, narrower than interspaces, dark brown in live specimens and dull white in preserved specimens, the bars reach ventral surface behind dorsal fin; dorsal fin with a row of spots at three quarters height; caudal fin plain with dissociated band at base with a central spot; other fins without any prominent colour pattern.

\section{Distribution}

Sharavathi river basin, Central Western Ghats, Karnataka, India.

\section{Discussion}

Schistura sharavathiensis resembles the species of the genus Longischistura Banarescu and Nalbant, only in the presence of a long adipose crest extending from a short distance behind

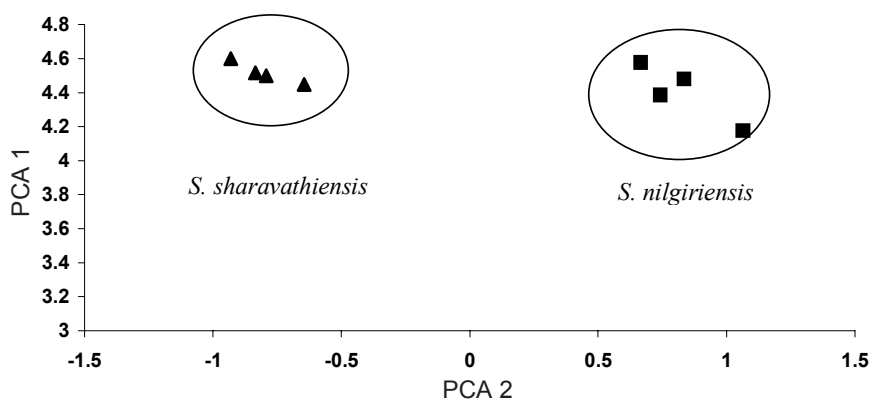

Figure 3. Plot of principal components of 31 morphological parameters - Schistura sharavathiensis and S. nilgiriensis

dorsal fin to caudal base; but differs with respect to 10 dorsal rays, deeply forked caudal fin, complete to almost complete lateral line in Longischistura genus. It also resembles genus Indoreonectes in long nasal barbel (Oreonectes genus, Kottelat, 1990) and adipose crest on the caudal peduncle. However, it differs from I. keralensis and I. evezardi in the presence of rounded and banded caudal fin, broad and incomplete, irregular vertical bands or mottled all over the body. The identity of the species is confirmed based on the available literatures of Schistura in South-Asian region (Menon, 1987; Kottelat, 1990; Talwar and Jhingran, 1991; Jayaram, 1999; Kottelat, 2004; Vishwanath and Nebeshwar, 2004; Vishwanath and Shanta, 2004; Vishwanath and Sharma, 2005). Table 3 shows the comparison between the six recorded taxa of Western Ghats, which reveals that $S$. sharavathiensis differs significantly from the congeners, except for $S$. nilgiriensis. It differs in the presence of 5-14 vertical bands and a black spot at anterior base of dorsal fin in S. nilgiriensis. Appendix-I gives the identification keys for species. Plot of principal components (of PCA) shows different clusters indicating variations between $S$. sharavathiensis and S. nilgiriensis (Fig. 3) with eigen values of 159.29 for PC 1 (accounts for 96.48\% variability) and 5.42 for PC 2.

\section{Comparative Material}

Schistura kodaguensis: 06.x.2004, Kootu Holé (12026'59"N$75^{\circ} 42^{\circ} 46^{\prime \prime E}$ ), about $8 \mathrm{~km}$ northwest of Mercara, Coorg, Karnataka, 2 exs. $23.0 \mathrm{~mm}$ SL and 29.0mm SL, coll. Sreekantha, Vishnu D. and Gururaja K.V., IISc/CES/WGBIS: 3-5-3-5-005.

Schistura nilgiriensis: 06.xi.2003, Sharavathi river, Niluvase (13 $\left.44^{\prime} 18^{\prime \prime} \mathrm{N}-75^{\circ} 06^{\prime} 30 " \mathrm{E}\right)$, Shimoga, Karnataka, 2 exs. 39.0mm SL. and 43.0mm SL, coll. Sameer Ali, Gururaja KV and Vishnu D, IISc/CES/WGBIS: 3-5-3-5-004.

Schistura denisoni denisoni: 21.xi.2003, Sharavathi river

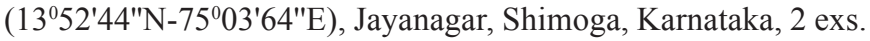
31.0mm SL and 39.0mm SL, coll. Sreekantha and Vishnu D, IISc/ CES/WGBIS: 3-5-3-5-001.

Schistura semiarmatus: $23 . x i .2003$, Sharavathi river $\left(75^{\circ} 03^{\prime} 52^{\prime \prime} \mathrm{N}-\right.$ $\left.13^{\circ} 52^{\prime} 45^{\prime \prime E}\right)$ Suttha, Shimoga, Karnataka, 2 exs. 32.0mm SL and 34.0mm SL. Coll. Sreekantha and Vishnu D, IISc/CES/WGBIS: 3-5-3-5-006. 
Table 1. Nophometric characteristics of Schistura nagodiensis sp. nov. and Schistura sharavathiensis sp. nov. (dimensions in $\mathrm{mm}$ )

\begin{tabular}{|c|c|c|c|c|c|c|c|c|}
\hline \multirow[t]{2}{*}{ Parameters } & \multicolumn{4}{|c|}{ Schistura nagodiensis } & \multicolumn{4}{|c|}{ Schistura sharavathiensis } \\
\hline & Holotype & Range ( $n=13)$ & Mean & SD & Holotype & Range $(n=4)$ & Mean & SD \\
\hline Total length & 34.0 & $28.0-34.0$ & 30.9 & 1.2 & 35.0 & $31.0-35.0$ & 32.5 & 1.7 \\
\hline Standard length & 28.0 & $23.0-28.0$ & 25.6 & 1.1 & 29.0 & $24.0-29.0$ & 26.2 & 1.7 \\
\hline Body depth & 3.7 & $3.0-5.0$ & 3.9 & 0.6 & 4.4 & $3.7-4.4$ & 4.0 & 2.1 \\
\hline Head length & 6.0 & $5.0-6.0$ & 5.4 & 0.5 & 5.4 & $5.3-5.9$ & 5.6 & 0.3 \\
\hline Head width & 3.8 & $2.7-3.8$ & 3.2 & 0.3 & 3.5 & $3.2-4.3$ & 3.7 & 0.3 \\
\hline Eye diameter & 1.3 & $0.9-1.5$ & 1.3 & 0.2 & 1.5 & $1.2-1.5$ & 1.4 & 0.5 \\
\hline Inter orbital width & 1.5 & $0.9-1.7$ & 1.3 & 0.2 & 1.6 & $1.2-1.8$ & 1.5 & 0.2 \\
\hline Width of mouth & 1.8 & $1.4-1.9$ & 1.6 & 0.2 & 1.9 & $1.9-2.4$ & 2.1 & 0.2 \\
\hline Snout length & 2.0 & $1.5-2.5$ & 1.9 & 0.3 & 2.6 & $2.1-2.6$ & 2.3 & 0.2 \\
\hline Height of head at occiput & 2.8 & $1.9-3.1$ & 2.6 & 0.3 & 3.3 & $3.0-3.4$ & 3.2 & 0.2 \\
\hline Pre-dorsal length & 14 & $11.7-14$ & 12.7 & 0.6 & 14.0 & $12.0-14.0$ & 13.2 & 0.2 \\
\hline Post dorsal length & 13.5 & $12.0-13.5$ & 12.6 & 0.5 & 13.7 & $12.0-13.7$ & 12.9 & 0.9 \\
\hline Inter-nostril distance & 1.4 & $0.6-1.5$ & 1.2 & 0.3 & 1.1 & $0.9-1.5$ & 1.2 & 0.7 \\
\hline Pre-pelvic distance & 14.5 & $11.3-14.5$ & 12.5 & 1.1 & 13.8 & $10.8-13.8$ & 12.1 & 0.3 \\
\hline Height of dorsal fin & 3.8 & $3.2-4.4$ & 3.9 & 0.3 & 5.8 & $5.1-5.8$ & 5.4 & 1.3 \\
\hline Length of base of dorsal fin & 4.7 & $3.1-4.7$ & 3.9 & 0.5 & 4.2 & $4.2-5.0$ & 4.4 & 0.3 \\
\hline LCPD & 4.3 & $3.3-4.5$ & 3.7 & 0.4 & 3.6 & $3.6-4.3$ & 4.0 & 0.4 \\
\hline HCPD & 3.5 & $2.8-3.9$ & 3.2 & 0.3 & 4.2 & $3.1-4.7$ & 3.8 & 0.3 \\
\hline Length of base of anal fin & 2.2 & $1.9-3.5$ & 2.4 & 0.4 & 2.7 & $1.6-2.7$ & 2.1 & 0.7 \\
\hline Length of pectoral fin & 4.2 & $3.8-4.7$ & 4.3 & 0.2 & 5.1 & $3.4-5.2$ & 4.6 & 0.6 \\
\hline Length of pelvic fin & 4.1 & $3.3-4.3$ & 3.9 & 0.3 & 4.7 & $3.7-4.7$ & 4.2 & 0.8 \\
\hline Pre-anal length & 19.0 & $15.0-19.0$ & 17.1 & 1.0 & 21.0 & $18.2-21.0$ & 19.1 & 0.4 \\
\hline Pre-anus length & 20.0 & $17.0-21.0$ & 18.7 & 1.2 & 18.0 & $14.3-18.0$ & 16.6 & 1.3 \\
\hline
\end{tabular}

HCPD - Height of caudal peduncle; LCPD - Length of caudal peduncle

Table 2. Proportional values of morphometry of Schistura nagodiensis sp. nov. and Schistura sharavathiensis sp. nov.

\begin{tabular}{|c|c|c|c|c|}
\hline \multirow[t]{2}{*}{ Parameters } & \multicolumn{2}{|c|}{ S. nagodiensis $(\mathrm{N}=13$ ) } & \multicolumn{2}{|c|}{ S. sharavathiensis $(\mathrm{N}=4)$} \\
\hline & Range & Mean \pm S.D. & Range & Mean \pm S.D. \\
\hline Standard length (mm) & $23.0-28.0$ & $28.0(\max )$ & $24.0-29.0$ & $29.0(\max )$ \\
\hline Total length (mm) & $28.0-34.0$ & $34.0(\max )$ & $31.0-35.0$ & $35.0(\max )$ \\
\hline \multicolumn{5}{|l|}{$\%$ Standard length } \\
\hline Body depth & $12.0-20.0$ & $15.2 \pm 2.3$ & $14.2-16.2$ & $15.3 \pm 0.9$ \\
\hline Head length & $19.2-26.1$ & $21.3 \pm 2.0$ & $18.6-22.7$ & $21.3 \pm 1.8$ \\
\hline Snout length & $6.4-10.0$ & $7.5 \pm 1.1$ & $8.1-9.6$ & $8.8 \pm 0.6$ \\
\hline Pre-dorsal length & $47.6-52.0$ & $49.8 \pm 1.4$ & $48.3-53.1$ & $50.3 \pm 1.9$ \\
\hline Pre-pelvic length & $45.2-56.0$ & $48.9 \pm 3.0$ & $43.5-47.7$ & $45.9 \pm 2.0$ \\
\hline Height of dorsal fin & $12.8-18.7$ & $15.3 \pm 1.6$ & $19.6-22.9$ & $20.8 \pm 1.5$ \\
\hline Base of dorsal fin & $11.9-17.2$ & $15.4 \pm 1.7$ & $14.5-19.2$ & $16.9 \pm 2.1$ \\
\hline Pectoral fin length & $15.0-20.4$ & $16.8 \pm 1.5$ & $13.1-20.0$ & $17.7 \pm 3.3$ \\
\hline Pelvic fin length & $13.2-16.5$ & $15.1 \pm 0.9$ & $14.2-18.3$ & $16.0 \pm 1.7$ \\
\hline Base of anal fin & $7.6-12.6$ & $9.3 \pm 1.4$ & $6.5-9.6$ & $8.0 \pm 1.6$ \\
\hline Length of caudal fin & $16.2-24.0$ & $20.9 \pm 2.2$ & $20.7-29.1$ & $24.0 \pm 3.6$ \\
\hline Length of caudal peduncle & $13.2-17.3$ & $14.7 \pm 1.2$ & $12.4-17.1$ & $15.4 \pm 2.1$ \\
\hline Pectoral fin to pelvic fin distance & $22.8-36.0$ & $27.6 \pm 3.6$ & $21.5-28.9$ & $24.6 \pm 3.2$ \\
\hline Pre-anal length & $68.0-80.0$ & $73.2 \pm 3.4$ & $70.0-75.8$ & $72.8 \pm 2.4$ \\
\hline \multicolumn{5}{|l|}{ Other proportions (\%) } \\
\hline VA in PA & $14.3-40.0$ & $26.7 \pm 8.9$ & $15.5-52.7$ & $33.9 \pm 16.5$ \\
\hline HCPD in LCPD & $62.2-97.1$ & $86.1 \pm 9.3$ & $75.6-116.7$ & $96.1 \pm 19.9$ \\
\hline Eye diameter in Snout length & $52.4-88.2$ & $67.7 \pm 11.3$ & $52.2-71.4$ & $62.4 \pm 8.9$ \\
\hline Snout length in Head length & $28.3-50.0$ & $35.4 \pm 6.5$ & $36.8-48.1$ & $41.4 \pm 5.4$ \\
\hline IOW in Eye diameter & $80.0-115.4$ & $98.1 \pm 9.5$ & $100.0-120.0$ & $106.6 \pm 9.4$ \\
\hline Eye diameter in Head length & $15.0-30.0$ & $23.7 \pm 4.2$ & $22.6-27.8$ & $25.5 \pm 2.2$ \\
\hline
\end{tabular}

VA in PA - Vent to anal fin origin in pelvic fin to anal fin; HCPD in LCPD - Height of caudal peduncle in length of caudal peduncle; IOW - Interorbital width 
Table 3. Comparison of morphological characters of Schistura of Western Ghats.

\begin{tabular}{|c|c|c|c|c|c|c|c|}
\hline Species & $\mathrm{SL}(\mathrm{mm})$ & $\begin{array}{l}\text { Pectoral } \\
\text { fin rays }\end{array}$ & $\begin{array}{l}\text { Black spot } \\
\text { on Dorsal fin }\end{array}$ & $\begin{array}{l}\text { Rows of spots } \\
\text { on caudal fin }\end{array}$ & Lateral line & Caudal fin shape & Bars on body \\
\hline Schistura nagodiensis sp. nov. & 28 & $7-9$ & Absent & Feeble & Incomplete & Deeply emarginated & $7-9$ \\
\hline Schistura sharavathiensis sp. nov. & v. 29 & 9 & $1 / 4^{\text {th }}$ the height & Absent & Incomplete & Slightly emarginated & $16-18$ thin bands \\
\hline Schistura denisoni denisoni & 51.1 & 11 & At the base & Present & Incomplete & Deeply emarginated & Variable \\
\hline Schistura denisoni pambaensis & 40 & 11 & At the base & Present & Incomplete & Deeply emarginated & $10-14$ \\
\hline $\begin{array}{l}\text { Schistura denisoni } \\
\text { mukambbikaensis }\end{array}$ & 36 & 10 & At the base & Present & Incomplete & Deeply emarginated & $5-6$ \\
\hline Schistura kodaguensis & 36 & 10 & Absent & Present & Incomplete & Slightly emarginated & $11-14$ \\
\hline Schistura semiarmatus & 56.5 & 11 & At the base & Present & Complete & Slightly forked & $9-10$ \\
\hline Schistura nilgiriensis & 51 & 10 & At the base & Absent & Incomplete & Emarginated & $11-13$ \\
\hline
\end{tabular}

Key to the Schistura species of the Western Ghats (modified after Jayaram, 1999).

1. Lateral line complete; body with bands and conspicuous black spots.

S. semiarmatus

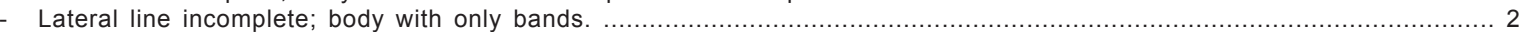

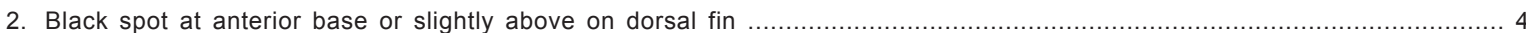

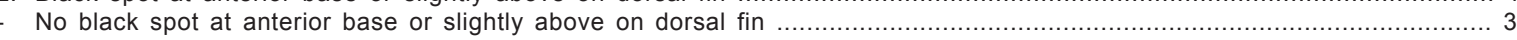

3. 11-14 black bars on body, black markings on lower lip absent, feeble if present, caudal fin emarginate .................. S. kodaguensis

- 6-9 black bars on body, two black markings on lower lip, caudal fin deeply emarginate or slightly forked .... S. nagodiensis sp.nov

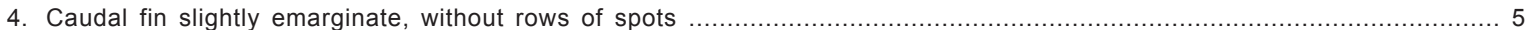

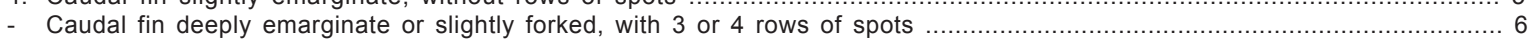

5. 11-12 brown bars, broader than interspaces; black spot at base of dorsal fin; moderately long nasal barbels ............. S. nilgiriensis

16-18 brown bars, narrower than interspaces; black spot at $1 / 4^{\text {th }}$ height of dorsal fin; very elongated nasal barbel ................... S. sharavathiensis sp.nov.

6. Body slender, about 6.5 times in SL; pelvic fin separated from anal opening by a considerable distance ...... S. denisoni pambaensis

- Body deeper, about 5 to 5.5 times in SL; pelvic fin reaching or almost reaching anal opening ............................................ 7

7. Pelvic fin reach anal opening; caudal fin deeply emarginate with several rows of spots; dorsal with rows of spots

S. denisoni denisoni

Pelvic fin falling short of anal opening; caudal fin slightly emarginate without conspicuous spots; dorsal with a dark base and a dark

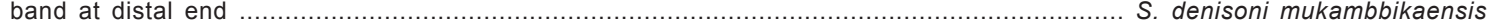

\section{REFERENCES}

Dahanukar, N., R. Raut and A. Bhat (2004). Distribution, endemism and threat status of freshwater fishes in the Western Ghats of India. Journal of Biogeography 31: 123-136.

Jayaram, K.C. (1999). The Freshwater Fishes of the Indian Region. Narendra Publishing House, New Delhi, 551pp.

Jayaram, K.C. (2002). Fundamentals of Fish Taxonomy. Narendra Publishing House, New Delhi, 174pp.

Kottelat, M. (1990). Indochinese nemacheilines: A revision of nemacheiline loaches (Pisces: Cypriniformes) of Thailand, Burma, Laos, Cambodia and southern Viet Nam. Verlag Dr. Friedrich Pfeil. Munchen, FRG, 262pp.

Kottelat, M. (2004). Schistura spekuli, a new species of cave fishes from northern Vietnam (Teleostei: Balitoridae). Ichthyological Exploration of Freshwaters 15(2): 187-191.

Menon, A.G.K. (1987). Fauna of India and the Adjacent Countries: Pisces, Vol. IV, Teleostei - Cobitoidae, Part 1, Homalopteridae, Zoological Survey of India, 259pp.

STATISTICA (1999). STATISTICA for Windows. StatSoft, Inc.

Talwar, P. K. and A.G. Jhingran, (1991). Inland Fishes of India and Adjacent Countries - Vol. 1, Oxford \& IBH Publishing Co. Pvt. Ltd, New Delhi, $541 \mathrm{pp}$.

Vidthayanon, C. (2003). Schistura pridii, a new nemacheiline loach (Teleostei: Balitoridae) from Upper Chao Phraya drainage, northern Thailand. Ichthyological Exploration of Freshwaters 14(4): 307-310.
Vishwanath, W. and K. Nebeshwar (2004). Schistura reticulata, a new species of balitorid loach from Manipur, India, with redescription of S. chindwinica. Ichthyological Exploration of Freshwaters 15(4): 323-330.

Vishwanath, W. and K. Shanta (2004). A new Nemacheiline fish of the genus Schistura McClelland (Cypriniformes: Balitoridae) from Manipur, India. Journal of the Bombay Natural History Society 101(1): $138-140$.

Vishwanath, W. and K.N. Sharma (2005). A new Nemacheiline fish of the genus Schistura McClelland (Cypriniformes: Balitoridae) from Manipur, India. Journal of the Bombay Natural History Society 102(1): $79-82$.

\section{ACKNOWLEDGEMENTS}

We are grateful to Dr. K.C. Jayaram, Chennai for invaluable suggestions during discussions. We acknowledge the financial assistance from the Ministry of Environment and Forests, Government of India. We thank the officials of Karnataka Forest Department and Karnataka Power Corporation Limited, Government of Karnataka for co-operation during the field investigation. We thank the Director and colleagues at ZSI, Southern Regional Station, Chennai for the support in identification of specimens. Suresh S., Vishnu D.M., Karthick B. and Ravindra assisted in specimens collection and Saveer Ahmed in digitizing mouth portion of specimens. 